\title{
DISCOVERY OF A NEW DEPOSIT OF THE SILURIAN SOFT-BODIED WAUKESHA BIOTA AND IMPLICATIONS FOR THE ORIGIN OF FOSSIL KONSERVAT LAGERSTÄTTEN
}

KLUESSENDORF, Joanne, Dept. of Geology, University of Illinois, $1301 \mathrm{~W}$. Green St., Urbana, IL 61801, U. S. A.; MIKULIC, Donald G., Illinois State Geological Survey, 615 E. Peabody Dr., Champaign, IL 61820, U.S.A.

A new deposit of exceptionally preserved Silurian soft-bodied fossils has been discovered in the Brandon Bridge strata (late Llandovery-early Wenlock) of Wisconsin. This second occurrence of the Waukesha biota has important implications for the origins of Fossil Konservat Lagerstätten and their role in diversity trends through time. Like the Burgess Shale and other similar Cambrian Lagerstätten, the Waukesha biota is not geographically unique. Rather, these biotas, which have low fossilization potential, were more widely distributed, and their present rarity reflects a paucity of appropriate preservational environments. The presence of two unusual taxa (Ainiktozoon and an enigmatic taxon) in the Waukesha biota, which previously were known only from the late Llandovery of Scotland, further demonstrates the true widespread nature of the organisms in this biota. Together, these two Waukesha biota sites provide a more complete picture of Early Silurian marine diversity than can be obtained from studying typical shelly fossil assemblages alone.

Although separated by $25 \mathrm{~km}$, both deposits of the Waukesha biota have a very similar combination of biologic, taphonomic, and depositional characteristics. The fossils at both sites were deposited under peritidal conditions and preserved in sediment traps related to karstic topography having a northeast-southwest regional trend. Softbodied fossils at both sites are dominated numerically by a diversity of arthropod or arthropod-like taxa, which are preserved as organic films or fluorapatite infillings. The absence of shelly sessile benthos is a conspicuous feature of both deposits. This absence, together with the dominance of arthropod molts over carcasses, implies these are taphonomic accumulations of easily transported debris that were deposited at a site having exceptional preservation potential; they do not represent living associations. Biologic differences between the two deposits of the Waukesha biota are similar to those in other multi-localityLagerstätten. Most importantly, the proportions of specific taxa differ significantly between the two sites. While fossils at the original locality were widely scattered across a $375 \mathrm{~m}$-long exposure, the new deposit is characterized by abundant specimens confined to a single localized accumulation.

The discovery of this new deposit of the Waukesha biota demonstrates that the location of Fossil Konservat Lagerstätten can be predicted. This new site was found by carefully identifying the specific depositional and taphonomic features of the original occurrence and searching for this combination at other exposures of Brandon Bridge strata as well as in other Silurian units with similar lithologies. Although exposures of the Brandon Bridge are extensive throughout Wisconsin and Illinois, this is only the second known occurrence of the Waukesha biota. 